\title{
Zooplankton respiratory Electron Transport System (ETS) activity in the Mediterranean Sea: spatial and diel variability
}

\author{
Roberta Minutoli*, Letterio Guglielmo \\ ULR CoNISMa, Department of Animal Biology and Marine Ecology, University of Messina, Salita Sperone 31, S. Agata, \\ 98166 Messina, Italy
}

\begin{abstract}
The zooplankton community plays a key role in biological carbon binding activity in the epipelagic marine ecosystem. The activity of the Electron Transport System (ETS), located in the mitochondrial membrane, is a specific and highly sensitive method to determine respiration rates and thus evaluate zooplankton carbon requirements. The present study focuses on the geographical distribution of zooplankton carbon demand and its day/night variability (measured over a $24 \mathrm{~h}$ period) in the top $200 \mathrm{~m}$ of the water column at 10 sampling stations throughout the Mediterranean Sea, from the Strait of Gibraltar to the Isle of Rhodes. To interpret the ETS data, species composition, abundance, and biomass (in mg wet weight $\mathrm{m}^{-3}$; $\mathrm{mg}$ wet wt $\mathrm{m}^{-3}$ ) of zooplankton were investigated. Oxygen consumption $\left(\mu \mathrm{O}_{2} \mathrm{~g}^{-1} \mathrm{~h}^{-1}\right)$ rates were recalculated for measured in situ temperatures, converted into carbon demand and expressed as $\mu \mathrm{g} \mathrm{C} \mathrm{g}$ wet $\mathrm{wt}^{-1} \mathrm{~d}^{-1}$. The carbon requirements per unit zooplankton biomass indicated spatial, geographical and day/night differences in the Mediterranean Sea. The data revealed an increasing gradient from the Strait of Gibraltar to the easternmost station near the Isle of Rhodes, going from a mean value of 240866 to $419344 \mu \mathrm{g} \mathrm{C} \mathrm{g} \mathrm{wet} \mathrm{wt}{ }^{-1} \mathrm{~d}^{-1}$. The relationship between zooplankton ETS activity and sea surface temperature was analysed. At all stations, ETS activities, and thus carbon demand, were higher in samples collected between sunset and sunrise than in those collected during daytime. This was related to actively migrating organisms that mediate the vertical transport of material in the sea.
\end{abstract}

KEY WORDS: Electron Transport System • Oxygen consumption - Carbon consumption . Zooplankton · Mediterranean Sea

\section{INTRODUCTION}

The accumulation and segregation of $\mathrm{CO}_{2}$ in the ocean has been a main topic of the international scientific community for many years. Carbon can be bound in the epi- and mesopelagic zones for months to several years (Koppelmann et al. 2000). All abiotic and biotic compartments in the ocean are involved in the transport and/or transformation of carbon. Among all these processes, the formation of particulate organic matter (POM) in the upper ocean plays a key role. The primary source of POM in the ocean is autotrophic, carbon-fixing phytoplankton organisms (Bradford-
Grieve et al. 2001). POM cycling in the ocean's interior is controlled by the interaction of physical, chemical and biological forces (Koppelmann et al. 2004). Many taxa use POM as a food source, thus decreasing the total amount. In fact, only $10 \%$ reaches the seafloor, while the main part is consumed, remineralized, and converted into new biomass (Berger et al. 1988, Koppelmann et al. 2000).

Among the consumers, a key role in carbon binding activity is played by the mesozooplankton community (Smith 1982, 1987, Sasaki et al. 1988, Longhurst 1991, Lampitt 1992, Steinberg et al. 1997, Koppelmann et al. 2000, Christiansen et al. 2001, Yamaguchi et al. 2002, 
Halsband-Lenk et al. 2003). The net contribution to remineralization (respiration) consists of ingestion minus defecation, growth and excretion (Lampitt 1992).

The determination of respiration rates based on electron transport system (ETS) activities is a specific and highly sensitive method to estimate the zooplankton carbon requirement and thus the proportion of carbon removed from the sinking flux (Packard 1971, King \& Packard 1975, Owens \& King 1975, Bamstedt 1979, 1980, Bidigare et al. 1982). The ETS, nearly ubiquitous in living organisms and located in the mitochondrial membranes, consists of a complex chain of cytochromes, flavoproteins and metabolic ions that transport electrons from catabolized foodstuffs to oxygen. The rate-limiting step is the oxidation of the coenzyme Q-cytochrome B complex, which can be measured by its reaction with the artificial electron acceptor 2-(p-iodophenyl)-3-(p-nitrophenyl)5-phenyl tetrazolium chloride (Packard 1971). This enzymatic transport is influenced by various factors such as temperature, salinity, and sexual stage (Torres et al. 1979, Ikeda \& Hing Fay 1981, Raymont 1983, Schalk 1988), even if acclimatization to environmental conditions is possible (Bamstedt 1980, Hirche 1984). High or low ETS values in zooplankton may indicate growing or declining populations, respectively, or the beginning or end of a phytoplankton bloom the zooplankton is feeding on. In fact, the relationships between respiratory activity and growth, reproduction, crowding and starvation have long been demonstrated (Schalk 1988). More than one study has shown a good correlation between ETS activity and in vivo respiration (Packard et al. 1974, Kenner \& Ahmed 1975b, Owens \& King 1975, Devol \& Packard 1978).
Geographical and seasonal differences in zooplankton respiratory activity in oceans have also been demonstrated (Marshall \& Orr 1956, Conover 1959, Conover \& Corner 1968, Gaudy 1973, Marshall 1973, Raymont 1983, Schalk 1988). However, data on ETS activities in mesozooplankton and micronekton of the Mediterranean Sea are scarce. The only region that has been investigated is the Levantine Sea near Crete, where only the ETS activity of deeper zooplankton was measured but the diel cycle was not analyzed (Halsband-Lenk et al. 2003, Koppelmann \& Weikert 2003, Koppelmann et al. 2004).

The present study focuses on geographical differences in zooplankton carbon demand and its diel variability at 10 stations, from a reference station in the Atlantic near the Strait of Gibraltar to the Isle of Rhodes in the Mediterranean Sea. To interpret the ETS data, the relative species composition, abundance and biomass were investigated and the relationships between ETS activity (oxygen and carbon demand) and composition and/or abundance of zooplankton and temperatures of the basins were determined.

\section{MATERIALS AND METHODS}

Field sampling. Samples were taken during the second and third legs of the TRANSMED oceanographic cruise (28 May to 28 June 2007) from Cadiz in the North Atlantic, through the Strait of Gibraltar and the western and eastern Mediterranean, to the Isle of Rhodes (Fig. 1). This expedition was part of the large Italian project VECTOR (VulnErability of the Italian coastal area and marine ecosystems to Climatic changes and Their rOle in mediterranean caRbon cycles). During the second leg (28 May to 12 June 2007), the

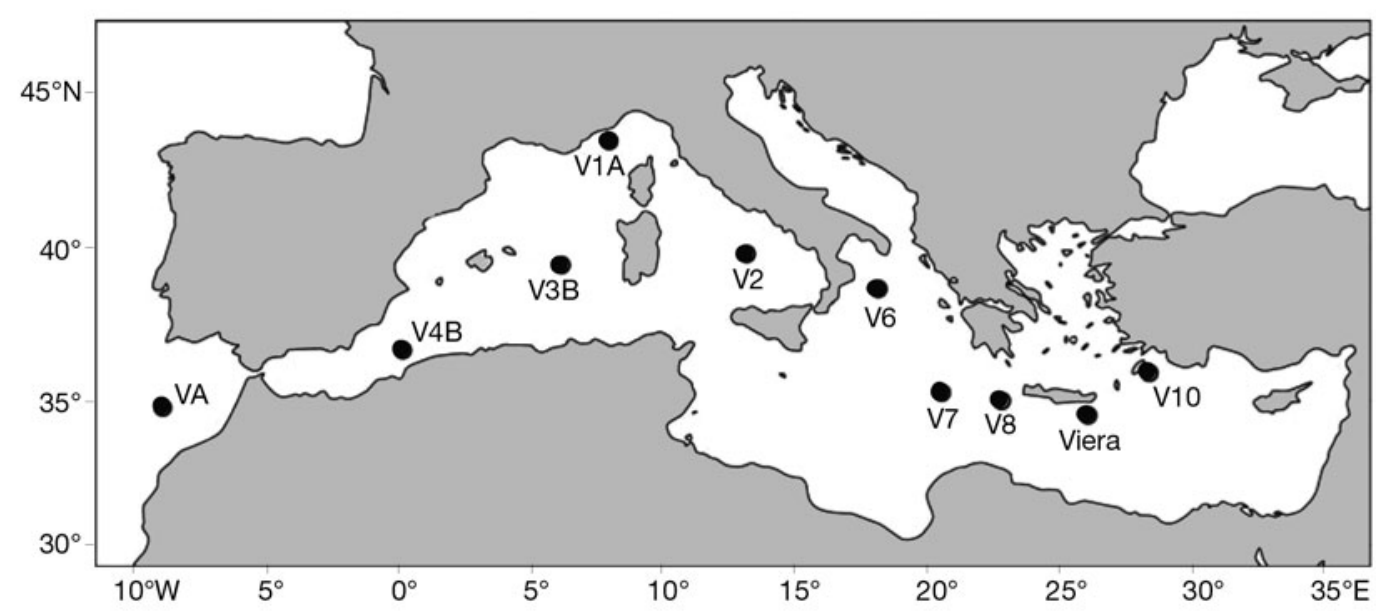

Fig. 1. Zooplankton sampling stations in the Mediterranean Sea during the second and third legs of the TRANSMED oceanographic cruise 28 May to 28 June 2007 
upper $200 \mathrm{~m}$ of the water column were sampled 4 times during a $24 \mathrm{~h}$ cycle $(06: 00,12: 00,18: 00,24: 00 \mathrm{~h})$ at 5 stations (VA, V4B, V3B, V1A, V2) in the western Mediterranean (WM) in order to study the change in zooplankton composition caused by diel vertical migrations and its potential relation with the obtained ETS values. At Stn V3B, only 3 samplings were carried out. During the third leg (12 to 28 June 2007), the upper $200 \mathrm{~m}$ of the water column were sampled at 5 stations (V6, V7, V8, Viera, V10) in the eastern Mediterranean (EM); however, during this cruise only 3 samplings were carried out over the $18 \mathrm{~h}$ available at each station, except at Stn V10 where it was possible to carry out 4 samplings. All sampling details are summarized in Table 1. If the actual time of sampling differed greatly from the intended sampling time, this is indicated to avoid misinterpretation of results.

A total of 35 samples were collected vertically using the $1 \mathrm{~m}^{2}$ Indian Ocean standard net (IOSN) with a mesh size of $335 \mu \mathrm{m}$. A flow meter (Hydro Bios) was connected to the net to measure the volume of seawater filtered by the net. On board, each sample was split into 2 aliquots of $1 \mathrm{l}$ : one aliquot was filtered through a $335 \mu \mathrm{m}$ mesh sieve and immediately frozen in liquid nitrogen for the ETS measurements; the other was preserved in $4 \%$ formaldehyde-seawater solution, buffered with sodium tetraborate (Steedman 1976), for the ecological qualitative and quantitative analyses.

Environmental parameters at the sampling stations were measured with a CTD SBE911 equipped with primary sensors for conductivity $(\mathrm{mS})$, temperature $\left({ }^{\circ} \mathrm{C}\right)$, depth $(\mathrm{m})$, fluorescence $(\mathrm{V})$, and dissolved oxygen $\left(\mathrm{ml} \mathrm{l}^{-1}\right)$.

Electron Transport System analysis. In the laboratory, ETS activity (as amount oxygen per gram wet weight per hour, $\mu \mathrm{l} \mathrm{O}_{2} \mathrm{~g}$ wet $\mathrm{wt}^{-1} \mathrm{~h}^{-1}$ ) as a measure of potential respiration and carbon demand was determined for the 35 frozen samples according to Packard (1971), Kenner \& Ahmed (1975a), Owens \& King (1975), Koppelmann et al. $(2000,2004)$, and calculated by the following equation:

$$
\mathrm{ETS}_{\text {assay }}=A_{\text {corr }} \times H \times S \times 60 / 1.42 \times W \times f \times t
$$

where $A_{\text {corr }}$ is the absorbance of the sample at $490 \mathrm{~nm}$ corrected for blank and reagents, $H$ is the homogenate volume in $\mathrm{ml}, S$ is the volume of the reaction mixture in

Table 1. Sampling details of the western and eastern leg of the 'VECTOR

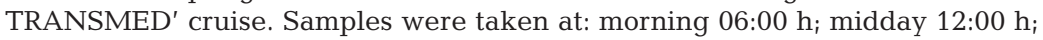
afternoon 18:00 $h_{i}$ midnight 00:00 $\mathrm{h}$. If the time of sampling differed, the exact time is given in parentheses

\begin{tabular}{|c|c|c|c|c|}
\hline $\begin{array}{l}\text { Stn } \\
\text { Sampling run }\end{array}$ & $\begin{array}{l}\text { Sampling date } \\
\text { (DD/MM/YY) }\end{array}$ & $\begin{array}{l}\text { Latitude } \\
\text { N }\end{array}$ & $\begin{array}{l}\text { Longitude } \\
\text { W }\end{array}$ & $\begin{array}{l}\text { Sampling } \\
\text { time }(\mathrm{h})\end{array}$ \\
\hline \multicolumn{5}{|c|}{ Eastern Mediterranean } \\
\hline \multicolumn{5}{|l|}{ VA } \\
\hline 1 & $29 / 05 / 07$ & $35^{\circ} 00^{\prime} 02^{\prime \prime}$ & $08^{\circ} 20^{\prime} 02^{\prime \prime}$ & Midday \\
\hline 2 & $29 / 05 / 07$ & $34^{\circ} 59^{\prime} 96^{\prime \prime}$ & $08^{\circ} 20^{\prime} 04^{\prime \prime}$ & Afternoon \\
\hline 3 & $30 / 05 / 07$ & $35^{\circ} 00^{\prime} 02^{\prime \prime}$ & $08^{\circ} 20^{\prime} 03^{\prime \prime}$ & Midnight \\
\hline 4 & $30 / 05 / 07$ & $34^{\circ} 59^{\prime} 86^{\prime \prime}$ & $08^{\circ} 19^{\prime} 96^{\prime \prime}$ & Morning (09:00) \\
\hline \multicolumn{5}{|l|}{ V4B } \\
\hline 1 & 01/06/07 & $36^{\circ} 29^{\prime} 99^{\prime \prime}$ & $00^{\circ} 59^{\prime} 98^{\prime \prime}$ & Morning \\
\hline 2 & 01/06/07 & $36^{\circ} 29^{\prime} 93^{\prime \prime}$ & $00^{\circ} 59^{\prime} 85^{\prime \prime}$ & Midday \\
\hline 3 & 01/06/07 & $36^{\circ} 30^{\prime} 01^{\prime \prime}$ & $00^{\circ} 59^{\prime} 97^{\prime \prime}$ & Afternoon \\
\hline 4 & 01/06/07 & $36^{\circ} 29^{\prime} 90^{\prime \prime}$ & $00^{\circ} 59^{\prime} 94^{\prime \prime}$ & Midnight \\
\hline \multicolumn{5}{|l|}{ V3B } \\
\hline 1 & 03/06/07 & $39^{\circ} 18^{\prime} 74^{\prime \prime}$ & $06^{\circ} 04^{\prime} 07^{\prime \prime}$ & Afternoon \\
\hline 2 & 04/06/07 & $39^{\circ} 18^{\prime} 79^{\prime \prime}$ & $06^{\circ} 04^{\prime} 17^{\prime \prime}$ & Morning \\
\hline 3 & 04/06/07 & $39^{\circ} 19^{\prime} 91^{\prime \prime}$ & $06^{\circ} 02^{\prime} 57^{\prime \prime}$ & Midday \\
\hline \multicolumn{5}{|l|}{ V1A } \\
\hline 1 & 05/06/07 & $43^{\circ} 29^{\prime} 98^{\prime \prime}$ & $08^{\circ} 00^{\prime} 01^{\prime \prime}$ & Afternoon \\
\hline 2 & 06/06/07 & $43^{\circ} 30^{\prime} 00^{\prime \prime}$ & $08^{\circ} 00^{\prime} 08^{\prime \prime}$ & Midnight \\
\hline 3 & 06/06/07 & $43^{\circ} 29^{\prime} 99^{\prime \prime}$ & $07^{\circ} 59^{\prime} 96^{\prime \prime}$ & Morning \\
\hline 4 & 06/06/07 & $43^{\circ} 30^{\prime} 04^{\prime \prime}$ & $07^{\circ} 59^{\prime} 39^{\prime \prime}$ & Midday \\
\hline \multicolumn{5}{|l|}{$\mathrm{V} 2$} \\
\hline 1 & 08/06/07 & $39^{\circ} 29^{\prime} 99^{\prime \prime}$ & $13^{\circ} 00^{\prime} 01^{\prime \prime}$ & Midnight \\
\hline 2 & 08/06/07 & $39^{\circ} 29^{\prime} 99^{\prime \prime}$ & $13^{\circ} 00^{\prime} 13^{\prime \prime}$ & Midday \\
\hline 3 & 08/06/07 & $39^{\circ} 29^{\prime} 93^{\prime \prime}$ & $13^{\circ} 00^{\prime} 06^{\prime \prime}$ & Afternoon $(20: 00)$ \\
\hline 4 & 08/06/07 & $39^{\circ} 29^{\prime} 93^{\prime \prime}$ & $12^{\circ} 59^{\prime} 99^{\prime \prime}$ & Midnight \\
\hline \multicolumn{5}{|c|}{ Western Mediterranean } \\
\hline \multicolumn{5}{|l|}{ V6 } \\
\hline 1 & $14 / 06 / 07$ & $38^{\circ} 29^{\prime} 42^{\prime \prime}$ & $17^{\circ} 60^{\prime} 00^{\prime \prime}$ & Midday \\
\hline 2 & $14 / 06 / 07$ & $38^{\circ} 29^{\prime} 21^{\prime \prime}$ & $17^{\circ} 59^{\prime} 45^{\prime \prime} \mathrm{E}$ & Afternoon \\
\hline 3 & $14 / 06 / 07$ & $38^{\circ} 29^{\prime} 36^{\prime \prime}$ & $17^{\circ} 59^{\prime} 36^{\prime \prime} \mathrm{E}$ & Midnight \\
\hline \multicolumn{5}{|l|}{ V7 } \\
\hline 1 & $16 / 06 / 07$ & $35^{\circ} 07^{\prime} 48^{\prime \prime}$ & $20^{\circ} 52^{\prime} 19^{\prime \prime}$ & Morning (08:30) \\
\hline 2 & $16 / 06 / 07$ & $35^{\circ} 08^{\prime} 10^{\prime \prime}$ & $20^{\circ} 51^{\prime} 52^{\prime \prime}$ & Midday \\
\hline 3 & $16 / 06 / 07$ & $35^{\circ} 08^{\prime} 23^{\prime \prime}$ & $20^{\circ} 54^{\prime} 19^{\prime \prime}$ & Afternoon $(20: 00)$ \\
\hline \multicolumn{5}{|l|}{ V8 } \\
\hline 1 & $17 / 06 / 07$ & $34^{\circ} 52^{\prime} 17^{\prime \prime}$ & $22^{\circ} 33^{\prime} 53^{\prime \prime}$ & Midday \\
\hline 2 & $17 / 06 / 07$ & $34^{\circ} 50^{\prime} 16^{\prime \prime}$ & $22^{\circ} 39^{\prime} 40^{\prime \prime}$ & Afternoon \\
\hline 3 & $17 / 06 / 07$ & $34^{\circ} 49^{\prime} 07^{\prime \prime}$ & $22^{\circ} 42^{\prime} 37^{\prime \prime}$ & Afternoon (20:30) \\
\hline \multicolumn{5}{|l|}{ Viera } \\
\hline 1 & $24 / 06 / 07$ & $34^{\circ} 24^{\prime} 48^{\prime \prime}$ & $26^{\circ} 04^{\prime} 52^{\prime \prime}$ & Midday \\
\hline 2 & $24 / 06 / 07$ & $34^{\circ} 24^{\prime} 14^{\prime \prime}$ & $26^{\circ} 05^{\prime} 29^{\prime \prime}$ & Afternoon \\
\hline 3 & $24 / 06 / 07$ & $34^{\circ} 25^{\prime} 20^{\prime \prime}$ & $26^{\circ} 05^{\prime} 31^{\prime \prime}$ & Midnight (22:00) \\
\hline \multicolumn{5}{|l|}{ V10 } \\
\hline 1 & $22 / 06 / 07$ & $35^{\circ} 57^{\prime} 13^{\prime \prime}$ & $28^{\circ} 19^{\prime} 19^{\prime \prime}$ & Midnight (22:00) \\
\hline 2 & $22 / 06 / 07$ & $35^{\circ} 55^{\prime} 30^{\prime \prime}$ & $28^{\circ} 19^{\prime} 17^{\prime \prime}$ & Midnight \\
\hline 3 & $23 / 06 / 07$ & $35^{\circ} 57^{\prime} 12^{\prime \prime}$ & $28^{\circ} 19^{\prime} 19^{\prime \prime}$ & Morning (08:30) \\
\hline 4 & $23 / 06 / 07$ & $35^{\circ} 56^{\prime} 18^{\prime \prime}$ & $28^{\circ} 19^{\prime} 12^{\prime \prime}$ & Midday \\
\hline
\end{tabular}


$\mathrm{ml}$, the factor 60 converts min to $\mathrm{h}, 1.42$ is the conversion factor of INT-formazan into $\mathrm{O}_{2}$ as $\mu \mathrm{l}, W$ is the wet weight of the incubated sample in $g$, $f$ is the volume of the homogenate in the assay in $\mathrm{ml}$ and $t$ is the incubation time in min.

The samples were incubated at $20^{\circ} \mathrm{C}$. To determine in situ ETS activities $\left(\right.$ ETS $_{\text {in situ }}, \mu \mathrm{O}_{2} \mathrm{~g}_{\text {wet }} \mathrm{wt}^{-1} \mathrm{~h}^{-1}$ ), all activities were recalculated for in situ temperatures using the Arrhenius equation, assuming an activation energy (Ea) of $13.2 \mathrm{kcal} \mathrm{mol}^{-1}$ for bathypelagic zooplankton (Packard et al. 1975):

$$
\mathrm{ETS}_{\text {in situ }}=\mathrm{ETS}_{\text {assay }} \times \mathrm{e}^{\left(\left(E a / R \times\left(1 / T_{\text {assay }}-1 / T_{\text {in }} \text { situ }\right)\right)\right.}
$$

where $R$ is the gas constant, $T_{\text {assay }}$ is the temperature of the assay and $T_{\text {in situ }}$ is the in situ temperature of the sampled sea water layers.

The rate of oxygen consumption per hour was converted into carbon demand per day, expressed as $\mu \mathrm{g} \mathrm{C}$ $\mathrm{g}$ wet wt $\mathrm{d}^{-1}$, assuming a respiration factor of 0.85 (King et al. 1978, Koppelmann et al. 2000):

$\operatorname{ETS}_{\text {assay }}\left(\mu \mathrm{g} \mathrm{C} \mathrm{g} \mathrm{wet} \mathrm{wt}^{-1} \mathrm{~d}^{-1}\right)=\operatorname{ETS}_{\text {assay }}\left(\mu \mathrm{l} \mathrm{O} \mathrm{O}_{2} \mathrm{~g}\right.$ wet $\left.\mathrm{wt}^{-1} \mathrm{~h}^{-1}\right) \times 0.85 \times 12 \times 24 / 22.4$

where 12 is the weight of $1 \mathrm{~mol} \mathrm{C}(\mathrm{g})$, the factor 24 converts $\mathrm{h}$ into $\mathrm{d}$ and 22.4 is the volume (in l) of 1 mol oxygen.

Table 2. Oxygen and carbon consumption rates (determined by electron transport system activity) of zooplankton collected in the 0 to $200 \mathrm{~m}$ layer during the $24 \mathrm{~h}$ cycle. See station and sampling time details in Table 1 . If the time of sampling differed, the exact time is given in parentheses

\begin{tabular}{|c|c|c|c|c|c|c|c|}
\hline Stn & $\begin{array}{l}\text { Sampling } \\
\text { run }\end{array}$ & \multicolumn{3}{|c|}{- Oxygen demand -} & \multicolumn{2}{|c|}{$\begin{array}{l}\text { Carbon demand } \\
\left(\mu g \mathrm{C} \mathrm{g}^{-1} \mathrm{~h}^{-1}\right)\left(\mu \mathrm{C}^{-1} \mathrm{~d}^{-1}\right)\end{array}$} & $\begin{array}{l}\text { Sampling } \\
\text { time }\end{array}$ \\
\hline \multicolumn{8}{|c|}{ Western Mediterranean } \\
\hline VA & $\begin{array}{l}1 \\
2 \\
3 \\
4\end{array}$ & $\begin{array}{l}27.59 \\
28.69 \\
45.75 \\
33.14\end{array}$ & $\begin{array}{l}17.99 \\
18.71 \\
29.84 \\
21.61\end{array}$ & $\begin{array}{l}0.80 \\
0.84 \\
1.33 \\
0.96\end{array}$ & $\begin{array}{r}8.19 \\
8.52 \\
13.59 \\
9.84\end{array}$ & $\begin{array}{l}197 \\
204 \\
326 \\
236\end{array}$ & $\begin{array}{c}\text { Midday } \\
\text { Afternoon } \\
\text { Midnight } \\
\text { Morning (09:00) }\end{array}$ \\
\hline V4B & $\begin{array}{l}1 \\
2 \\
3 \\
4\end{array}$ & $\begin{array}{l}49.29 \\
43.77 \\
41.28 \\
60.05\end{array}$ & $\begin{array}{l}27.41 \\
24.34 \\
22.96 \\
33.39\end{array}$ & $\begin{array}{l}1.22 \\
1.09 \\
1.02 \\
1.49\end{array}$ & $\begin{array}{l}12.48 \\
11.08 \\
10.45 \\
15.21\end{array}$ & $\begin{array}{l}299 \\
266 \\
251 \\
365\end{array}$ & $\begin{array}{l}\text { Morning } \\
\text { Midday } \\
\text { Afternoon } \\
\text { Midnight }\end{array}$ \\
\hline V3B & $\begin{array}{l}1 \\
2 \\
3\end{array}$ & $\begin{array}{l}41.21 \\
56.04 \\
42.83\end{array}$ & $\begin{array}{l}25.02 \\
34.03 \\
26.01\end{array}$ & $\begin{array}{l}1.12 \\
1.52 \\
1.16\end{array}$ & $\begin{array}{l}11.39 \\
15.49 \\
11.84\end{array}$ & $\begin{array}{l}273 \\
372 \\
284\end{array}$ & $\begin{array}{l}\text { Afternoon } \\
\text { Morning } \\
\text { Midday }\end{array}$ \\
\hline V1A & $\begin{array}{l}1 \\
2 \\
3 \\
4\end{array}$ & $\begin{array}{l}45.20 \\
64.63 \\
53.53 \\
41.10\end{array}$ & $\begin{array}{l}23.76 \\
33.97 \\
28.14 \\
21.60\end{array}$ & $\begin{array}{l}1.06 \\
1.52 \\
1.26 \\
0.96\end{array}$ & $\begin{array}{r}10.82 \\
15.47 \\
12.81 \\
9.84\end{array}$ & $\begin{array}{l}260 \\
371 \\
307 \\
236\end{array}$ & $\begin{array}{l}\text { Afternoon } \\
\text { Midnight } \\
\text { Morning } \\
\text { Midday }\end{array}$ \\
\hline $\mathrm{V} 2$ & $\begin{array}{l}1 \\
2 \\
3 \\
4\end{array}$ & $\begin{array}{l}52.94 \\
41.87 \\
43.78 \\
54.39\end{array}$ & $\begin{array}{l}31.14 \\
24.63 \\
25.75 \\
31.99\end{array}$ & $\begin{array}{l}1.39 \\
1.10 \\
1.15 \\
1.43\end{array}$ & $\begin{array}{l}14.18 \\
11.21 \\
11.73 \\
14.57\end{array}$ & $\begin{array}{l}340 \\
269 \\
281 \\
350\end{array}$ & $\begin{array}{c}\text { Midnight } \\
\text { Midday } \\
\text { Afternoon (20:00) } \\
\text { Midnight }\end{array}$ \\
\hline \multicolumn{8}{|c|}{ Eastern Mediterranean } \\
\hline V6 & $\begin{array}{l}1 \\
2 \\
3\end{array}$ & $\begin{array}{l}42.77 \\
40.18 \\
51.37\end{array}$ & $\begin{array}{l}27.45 \\
25.80 \\
32.98\end{array}$ & $\begin{array}{l}1.23 \\
1.15 \\
1.47\end{array}$ & $\begin{array}{l}12.50 \\
11.75 \\
15.02\end{array}$ & $\begin{array}{l}300 \\
282 \\
360\end{array}$ & $\begin{array}{l}\text { Midday } \\
\text { Afternoon } \\
\text { Midnight }\end{array}$ \\
\hline V7 & $\begin{array}{l}1 \\
2 \\
3\end{array}$ & $\begin{array}{l}47.76 \\
49.37 \\
57.22\end{array}$ & $\begin{array}{l}31.65 \\
32.72 \\
37.91\end{array}$ & $\begin{array}{l}1.41 \\
1.46 \\
1.69\end{array}$ & $\begin{array}{l}14.41 \\
14.90 \\
17.26\end{array}$ & $\begin{array}{l}346 \\
357 \\
414\end{array}$ & $\begin{array}{c}\text { Morning (08:30) } \\
\text { Midday } \\
\text { Afternoon (20:00) }\end{array}$ \\
\hline V8 & $\begin{array}{l}1 \\
2 \\
3\end{array}$ & $\begin{array}{l}61.65 \\
60.32 \\
63.34\end{array}$ & $\begin{array}{l}39.27 \\
38.42 \\
40.34\end{array}$ & $\begin{array}{l}1.75 \\
1.71 \\
1.80\end{array}$ & $\begin{array}{l}17.88 \\
17.49 \\
18.37\end{array}$ & $\begin{array}{l}429 \\
420 \\
441\end{array}$ & $\begin{array}{c}\text { Midday } \\
\text { Afternoon } \\
\text { Afternoon }(20: 30)\end{array}$ \\
\hline Viera & $\begin{array}{l}1 \\
2 \\
3\end{array}$ & $\begin{array}{l}45.63 \\
47.99 \\
50.86\end{array}$ & $\begin{array}{l}34.56 \\
36.35 \\
38.52\end{array}$ & $\begin{array}{l}1.54 \\
1.62 \\
1.72\end{array}$ & $\begin{array}{l}15.74 \\
16.55 \\
17.54\end{array}$ & $\begin{array}{l}378 \\
397 \\
421\end{array}$ & $\begin{array}{c}\text { Midday } \\
\text { Afternoon } \\
\text { Midnight }(22: 00)\end{array}$ \\
\hline V10 & $\begin{array}{l}1 \\
2 \\
3 \\
4\end{array}$ & $\begin{array}{l}65.70 \\
66.56 \\
51.58 \\
53.35\end{array}$ & $\begin{array}{l}42.51 \\
43.07 \\
33.38 \\
34.53\end{array}$ & $\begin{array}{l}1.90 \\
1.92 \\
1.49 \\
1.54\end{array}$ & $\begin{array}{l}19.36 \\
19.61 \\
15.20 \\
15.72\end{array}$ & $\begin{array}{l}464 \\
471 \\
365 \\
377\end{array}$ & $\begin{array}{c}\text { Midnight (22:00) } \\
\text { Midnight } \\
\text { Morning (8:30) } \\
\text { Midday }\end{array}$ \\
\hline
\end{tabular}


The ratio for converting measured ETS activities to in situ oxygen consumption for natural zooplankton assemblages is 0.5 (Kenner \& Ahmed 1975a,b, King \& Packard 1975, Hernandez-Leon \& Gomez 1996, Koppelmann et al. 2000). Packard (1971) and Packard \& Richards (1971) suggested that ETS activity, as measured by INT reduction in homogenates, can be used as a reliable index of in situ oxygen consumption. The values computed for R:ETS are reasonable, assuming that the ETS activity is measured at or near the $\mathrm{V}_{\max }$ of electron transfer.

Zooplankton abundance and biomass. Qualitative and quantitative analyses were carried out on the 35 preserved samples. To determine total zooplankton abundances, subsamples of $1 / 10$ to $1 / 25$ of any 11 sample were taken and sorted under a stereomicroscope (Leica Wild M10). The entire sample was sorted for the identification of rare species and micronekton. All organisms of each taxon were counted and classified at higher taxonomic levels, while species-level identification was carried out only for the main groups, including copepods, cladocerans, euphausiids, and chaetognaths. All data were reported as total abundance in $2 \mathrm{l}$, divided by the volume of seawater filtered during net tows, and expressed as ind. $\mathrm{m}^{-3}$.

For the biomass analysis, a $250 \mathrm{ml}$ subsample from each 11 sample was obtained using a Folsom Splitter and wet weighed according to the method of Tranter (1962). Biomass values were expressed as $\mathrm{mg} \mathrm{m}^{-3}$ of filtered seawater.

\section{RESULTS}

\section{Spatial patterns in carbon demand}

Oxygen consumption ( $\mu \mathrm{O}_{2} \mathrm{~g}^{-1} \mathrm{~h}^{-1}$ ) as measured by ETS activity, recalculated for in situ temperature and subsequently converted into carbon demand $\left(\mu \mathrm{g} \mathrm{C} \mathrm{g}^{-1}\right.$ $\mathrm{d}^{-1}$ ) of zooplankton in all samples collected in the 0 to $200 \mathrm{~m}$ layer during the $24 \mathrm{~h}$ cycle are shown in Table 2.

The biochemical analyses showed differences in mean carbon consumption rates between the samples from western and eastern stations. In fact, the mean value of the 19 samples collected in the western sector was $290 \mu \mathrm{g} \mathrm{C} \mathrm{g}{ }^{-1}$ $\mathrm{d}^{-1}$, compared to $387 \mu \mathrm{g} \mathrm{C} \mathrm{g}{ }^{-1} \mathrm{~d}^{-1}$ in the 16 samples collected in the Levantine Basin. Mean values for the different sampling times at each station are reported in Fig. 2. An increasing gradient in carbon demand from a mean

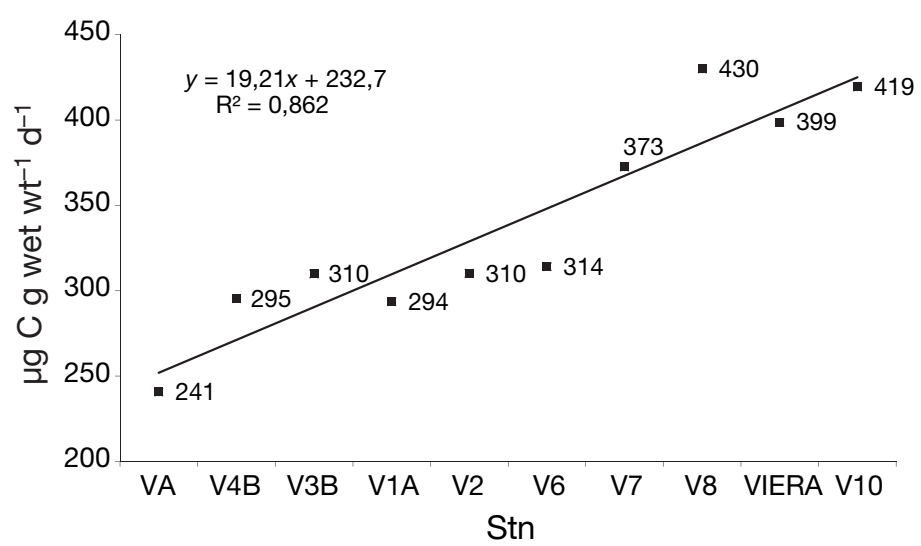

Fig. 2. Mean carbon consumption $\left(\mu g \mathrm{C} \mathrm{g}^{-1} \mathrm{~d}^{-1}\right)$, calculated by electron transport system activity, per gram wet weight of mixed 0 to $200 \mathrm{~m}$ depth zooplankton from all sampling stations

value of $241 \mu \mathrm{Cg}^{-1} \mathrm{~d}^{-1}$ at the Strait of Gibraltar to $419 \mu \mathrm{g} \mathrm{C} \mathrm{g}^{-1} \mathrm{~d}^{-1}$ at the easternmost station near the Isle of Rhodes was detected, with a significant $\mathrm{R}^{2}$ value of 0.86 for the regression line (Fig. 2) (ANOVA p $<0.5 \%$, $F=2.32$; Table 3 ).

Trends for carbon demands per unit biomass of zooplankton in all morning, midday, afternoon and midnight samples, which showed the same profile of the mean, are reported in Fig. 3. The values in the samples collected in the WM ranged from a minimum of $197 \mu \mathrm{g}$ $\mathrm{C}^{-1} \mathrm{~d}^{-1}$ in the midday samples from Stn VA to a maximum value of $372 \mu \mathrm{g} \mathrm{C} \mathrm{g}^{-1} \mathrm{~d}^{-1}$ for the morning sampling, before sunrise, at Stn V3B. The station showing the lowest minimum mean value was VA $\left(241 \mu \mathrm{g} \mathrm{C} \mathrm{g}^{-1}\right.$ $\mathrm{d}^{-1}$ ), while that with the mean highest ETS value during the different times in $24 \mathrm{~h}$, was V2 (311 $\mathrm{ug} \mathrm{C} \mathrm{g}^{-1}$ $\mathrm{d}^{-1}$ ), off Naples in the Tyrrhenian Sea. Among the zooplankton samples collected during the Levantine leg, data ranged from a minimum value of $282 \mu \mathrm{g} \mathrm{C} \mathrm{g}^{-1} \mathrm{~d}^{-1}$, for the afternoon zooplankton sampling at Stn V6 to a maximum value of $471 \mu \mathrm{g} \mathrm{C} \mathrm{g}^{-1} \mathrm{~d}^{-1}$ for the midnight sampling at Stn V8. The station that showed the lowest minimum mean value of ETS activity was V6 (314 $\mu \mathrm{g} \mathrm{C}$ $\left.\mathrm{g}^{-1} \mathrm{~d}^{-1}\right)$, while that with the highest mean value was V8 (429.94 $\mu \mathrm{g} \mathrm{C} \mathrm{g}^{-1} \mathrm{~d}^{-1}$ ), similar to the easternmost V10 $\left(419 \mu \mathrm{g} \mathrm{C} \mathrm{g}{ }^{-1} \mathrm{~d}^{-1}\right)$.

Table 3. Differences in electron transport system activity between western and eastern Mediterranean and among sampling groups, as determined by ANOVA

\begin{tabular}{|lrrrrr|}
\hline Source & $\begin{array}{c}\text { Deviance } \\
\text { Sums of squares }\end{array}$ & df & $\begin{array}{c}\text { Variance } \\
\text { Mean squares }\end{array}$ & F & $\begin{array}{c}\mathrm{p} \\
(\%)\end{array}$ \\
\hline Between means & 102125.3 & 9 & 11347.3 & 2.32 & $\mathrm{p}<0.5$ \\
Within Time samplings & 25068.9 & 3 & 8356.3 & 3.15 & $\mathrm{p}<0.1$ \\
Error & 26320.6 & 19 & 1385.3 & & \\
Total & 153514.8 & 31 & & & \\
\hline
\end{tabular}




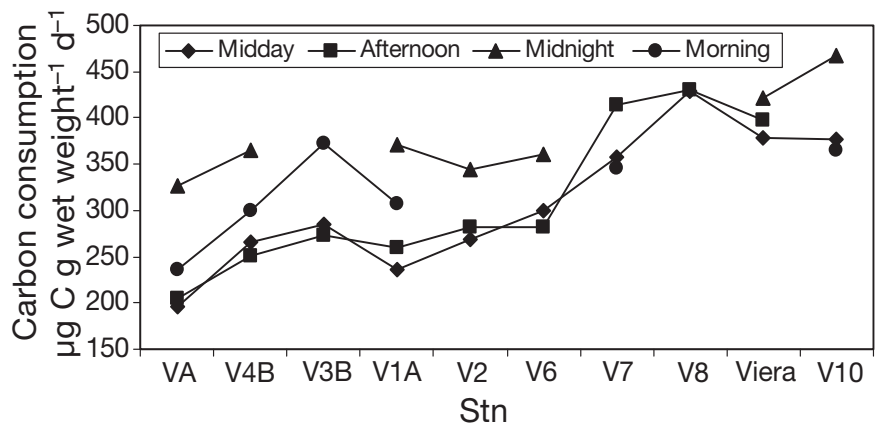

Fig. 3. Carbon consumption, calculated by electron transport system activity, plotted separately for morning $(06: 00 \mathrm{~h})$, midday $(12: 00 \mathrm{~h})$, afternoon $(18: 00 \mathrm{~h})$ and midnight $(00: 00 \mathrm{~h})$ zooplankton samples (where the time sampling differed, this is reported in Table 1)

ANOVA, applied to groups of data for the 4 sampling occasions, showed a statistically significant west-east trend for all sampling times, with an F-value of 3.15 $(\mathrm{p}<0.1 \%)$ (Table 3$)$.

\section{Diel variability}

The ETS analyses indicated diel differences in zooplankton distribution in the 0 to $200 \mathrm{~m}$ water layer
(Table 2). Higher values were found in the samples collected between sunset and sunrise at all stations, compared to those taken during the day. For example, the carbon requirement of samples from the westernmost Stn VA (out of the Strait of Gibraltar) was $326 \mu \mathrm{g} \mathrm{C} \mathrm{g}^{-1}$ $\mathrm{d}^{-1}$ in the midnight sample compared to $197 \mu \mathrm{g} \mathrm{C} \mathrm{g}^{-1}$ $\mathrm{d}^{-1}$ in the sample taken at midday; at the easternmost Stn V10 (near Rhodes), the carbon requirement of the midnight sample was $471 \mu \mathrm{g} \mathrm{C} \mathrm{g} \mathrm{C}^{-1} \mathrm{~d}^{-1}$ compared to $377 \mu \mathrm{g} \mathrm{C} \mathrm{g}^{-1} \mathrm{~d}^{-1}$ in the midday sample.

\section{Zooplankton composition and abundance}

Table 4 shows the results of the qualitative and quantitative analyses of the samples taken at midday at all 10 sampling stations. Concerning general taxonomic composition, the western stations showed the same mean value of identified taxa (17) as the eastern stations, with the highest number (22) observed at Stn VA and the lowest (13) at Stn V1A.

Total mean zooplankton abundances in the midday samples was higher for the western (64.17 ind. $\mathrm{m}^{-3}$ ) compared to the eastern sector (32.43 ind. $\mathrm{m}^{-3}$ ). The lowest abundances were found in the 3 samples taken from midday to evening at the eastern Stn V8 (15.69,

Table 4. Abundances (ind. $\mathrm{m}^{-3}$ ) of total zooplankton, crustacean, tunicate and gelatinous taxa identified in the midday (12:00 h) collections at the 10 sampling stations. Stn details are given in Table 1

\begin{tabular}{|c|c|c|c|c|c|c|c|c|c|c|}
\hline Taxa & VA & V4B & V3B & V1A & $\mathrm{V} 2$ & V6 & V7 & V8 & Viera & V10 \\
\hline Total zooplankton ${ }^{\mathrm{a}}$ & 32.25 & 103.31 & 22.18 & 129.37 & 33.74 & 24.49 & 36.23 & 15.69 & 26.87 & 58.89 \\
\hline \multicolumn{11}{|l|}{ Crustacea } \\
\hline Amphipoda & 0.12 & 0.00 & 0.00 & 0.03 & 0.14 & 0.08 & 0.29 & 0.05 & 0.00 & 0.35 \\
\hline Copepoda & 25.24 & 35.11 & 8.42 & 119.78 & 22.58 & 16.98 & 22.56 & 10.62 & 13.67 & 41.00 \\
\hline Copepoda nauplii & 0.00 & 0.00 & 0.00 & 0.00 & 0.07 & 0.00 & 1.42 & 0.00 & 0.30 & 0.35 \\
\hline Cladocera & 0.47 & 34.51 & 1.79 & 3.47 & 2.11 & 0.00 & 0.00 & 0.18 & 0.00 & 0.00 \\
\hline Decapoda & 0.00 & 0.00 & 0.00 & 0.00 & 0.00 & 0.00 & 0.00 & 0.00 & 0.00 & 0.00 \\
\hline $\begin{array}{l}\text { Euphausiacea adults and } \\
\text { juveniles }\end{array}$ & 0.03 & 0.00 & 0.13 & 0.03 & 0.00 & 0.09 & 0.06 & 0.06 & 0.00 & 0.00 \\
\hline Euphausiacea nauplii & 0.00 & 0.00 & 0.00 & 0.00 & 0.00 & 0.00 & 0.00 & 0.00 & 0.00 & 0.00 \\
\hline Calyptopis & 0.12 & 0.30 & 0.00 & 2.15 & 0.00 & 0.26 & 0.22 & 0.00 & 0.00 & 0.00 \\
\hline Furciliae & 0.13 & 0.09 & 0.03 & 0.49 & 0.14 & 0.00 & 0.06 & 0.08 & 0.01 & 0.01 \\
\hline Misidacea & 0.00 & 0.00 & 0.00 & 0.00 & 0.00 & 0.00 & 0.00 & 0.00 & 0.00 & 0.00 \\
\hline Ostracoda & 0.47 & 2.12 & 0.38 & 0.33 & 1.09 & 1.15 & 0.97 & 0.48 & 0.90 & 0.96 \\
\hline Total & 26.58 & 72.13 & 10.75 & 126.29 & 26.13 & 18.56 & 25.58 & 11.47 & 14.88 & 42.67 \\
\hline \multicolumn{11}{|l|}{ Tunicata } \\
\hline Appendicularia & 2.13 & 4.54 & 2.31 & 0.99 & 2.58 & 0.88 & 2.54 & 0.54 & 2.00 & 1.84 \\
\hline Chaetognata & 0.24 & 3.63 & 4.24 & 0.03 & 0.27 & 0.00 & 2.54 & 1.50 & 1.60 & 5.70 \\
\hline Total & 2.36 & 8.17 & 6.55 & 1.02 & 2.85 & 0.88 & 5.08 & 2.04 & 3.60 & 7.54 \\
\hline \multicolumn{11}{|l|}{ Gelatinous zooplankton } \\
\hline Doliolida & 0.94 & 15.44 & 1.28 & 0.00 & 0.07 & 0.18 & 2.17 & 0.24 & 0.40 & 4.91 \\
\hline Idromedusae & 0.35 & 0.91 & 2.18 & 0.16 & 0.75 & 0.08 & 0.15 & 0.00 & 1.20 & 0.35 \\
\hline Salpae & 0.00 & 0.00 & 0.00 & 0.00 & 0.14 & 0.00 & 0.00 & 0.00 & 0.20 & 0.00 \\
\hline Siphonophora & 0.83 & 2.72 & 0.77 & 0.49 & 2.31 & 2.30 & 1.19 & 1.08 & 0.60 & 2.54 \\
\hline Total & 1.30 & 16.35 & 3.46 & 0.16 & 0.96 & 0.26 & 2.32 & 0.24 & 1.80 & 5.26 \\
\hline
\end{tabular}




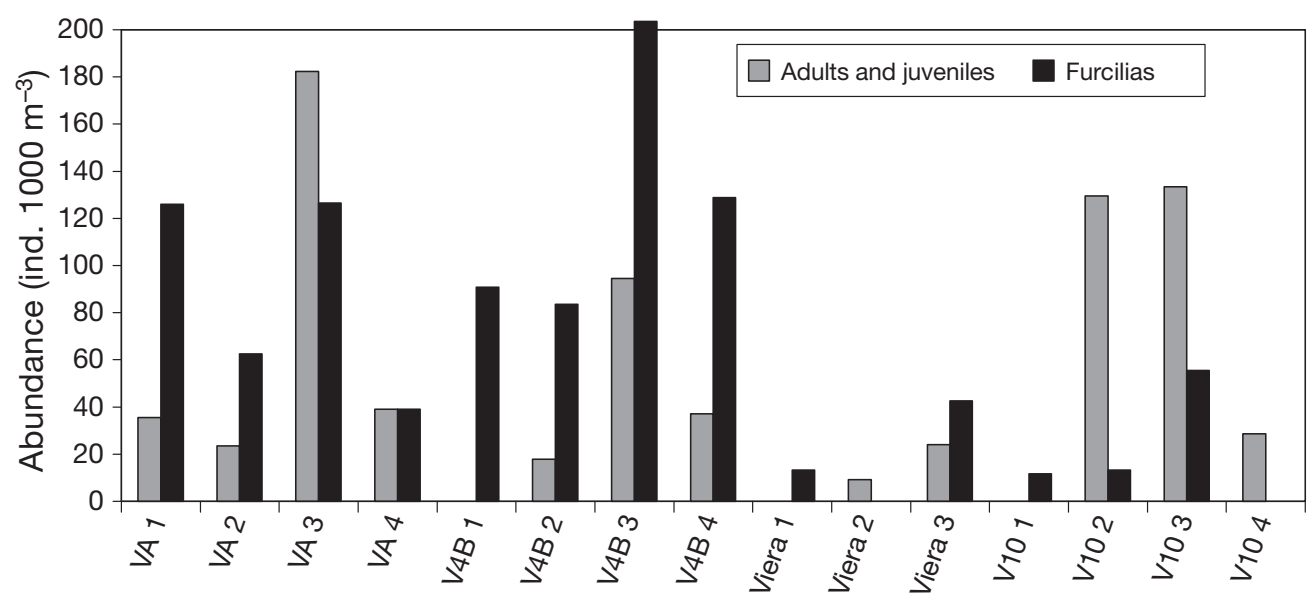

Fig. 4. Density (ind. $1000 \mathrm{~m}^{-3}$ ) of adults and juvenile and furcilia stages of euphausiids, for zooplankton samples from Stns VA and V4B (western Mediterranean) and Viera and V10 (eastern Mediterranean) at 1: midday (12:00 h), 2: afternoon (18:00 h except Stn V10: 22:00 h), 3: midnight (00:00 h except Stn Viera: 22:00 h), 4: morning (06:00 h except Stns VA: 09:00 h and V10: 08:30 h)

20.86 and 19.92 ind. $\mathrm{m}^{-3}$ ), and the highest occurred in the 4 samples taken over a $24 \mathrm{~h}$ period from the western Stn V1A (108.35, 118.86, 76.11 and 129.37 ind. $\mathrm{m}^{-3}$ ).

Copepods were the dominant group in all 35 analysed samples, ranging from $33.99 \%$ (midday sample at V4B) to $97.5 \%$ (afternoon sample at V1A) of all identified zooplankton taxa. Abundances were between 6.46 ind. $\mathrm{m}^{-3}$ in the afternoon sample at Stn V3B and 119.78 ind. $\mathrm{m}^{-3}$ in the midday sample at Stn V1A. The highest number of identified copepod species at all stations was 67 at Stn V7, while the lowest was 19 at Stn V3B.

To interpret the ETS data obtained at the different stations and times, the ratio between crustaceans and gelatinous taxa and the abundances of migrant species were determined. The relative abundance of crustacea in the midday samples from all 10 stations (Table 4) ranged from $48.47 \%$ (Stn V3B) to $97.62 \%$ (Stn V1A) in the western compared to $55.38 \%$ (Stn Viera) to $75.79 \%$ (Stn V6) in the eastern sector. In contrast, the gelatinous taxa represented from $0.50 \%$ (Stn V1A) to $19.07 \%$ (Stn V3B) of the total zooplankton community for the western compared to $8.41 \%$ (Stn V8) to $13.24 \%$ (Stn V10) for the eastern sector. In the samples collected at midday, the ratio between gelatinous and crustacean taxa was almost equal across all stations, without significant differences from west (mean ratio 1:7.2) to east (mean ratio 1:7), except for Stn V1A where the total gelatinous specimens were $<1$ ind. $\mathrm{m}^{-3}$ and where the crustaceans showed the highest density of all samples collected (126.29 ind. $\mathrm{m}^{-3}$ ).

Regarding the study of migrant groups, euphausiid densities in the samples collected during the $24 \mathrm{~h}$ periods were determined to investigate possible correla- tions of migration patterns with ETS activities. Fig. 4 shows the combined densities of adults and juveniles and those of furcilia stages for every sample from the 2 western- and easternmost sampling stations. The calyptopids were not considered because they were evidently less active, restricted to the surface layer, and did not show diel vertical migration (Marschoff et al. 1989, Stuart \& Pillar 1990). The analyses of euphausiids reflected vertical migration patterns. Of the selected western stations, Stn VA showed higher a density of adults and juveniles (182.33 ind. $1000 \mathrm{~m}^{-3}$ ) and furcilias (126.43 ind. $1000 \mathrm{~m}^{-3}$ ) at night. Similarly, at Stn V4B, high densities were found in the midnight sample (adults + juveniles 94.51 ind. $1000 \mathrm{~m}^{-3}$; furcilias 203.56 ind. $1000 \mathrm{~m}^{-3}$ ). The same was observed at the eastern stations: at Stn Viera, where all taxa showed very low total abundances, adults and juveniles (23.95 ind. $1000 \mathrm{~m}^{-3}$ ) and furcilia stages (42.58 ind. $1000 \mathrm{~m}^{-3}$ ) of euphausiids were most abundant in the sample collected at 22:00 $h_{\text {; }}$ at Stn V10, the sample with the highest density of adults plus juveniles (133.33 ind. $1000 \mathrm{~m}^{-3}$ ) and furcilias (55.56 ind. $1000 \mathrm{~m}^{-3}$ ) was that collected at midnight.

In Table 5, the abundances (ind. $1000 \mathrm{~m}^{-3}$ ) and the relative percent frequencies $(\mathrm{F} \%)$ of all sampled euphausiid species for the 2 westernmost and 2 easternmost stations are reported. Higher abundance values were found in the WM (429.74 ind. $1000 \mathrm{~m}^{-3}$ ) with respect to the EM (324.53 ind. $1000 \mathrm{~m}^{-3}$ ). We found 9 euphausiid species in the western basin while 8 were found in the Levantine Basin. Stylocheiron abbreviatum was the most abundant species in both basins, followed by $S$. longicorne and Euphausia hemigibba in the WM and by E. brevis and E. hemigibba in the EM. 
Table 5. Euphausiid species abundances (ind. $1000 \mathrm{~m}^{-3}$ ) in samples taken at different times at the 2 westernmost and the 2 easternmost Mediterranean stations

\begin{tabular}{|c|c|c|c|c|c|c|c|c|c|c|}
\hline $\begin{array}{l}\text { Western Mediterranean } \\
\text { Stn } \\
\text { Time sampling }\end{array}$ & $\begin{array}{l}\text { VA } 1 \\
12: 00\end{array}$ & $\begin{array}{l}\text { VA } 2 \\
18: 00\end{array}$ & $\begin{array}{l}\text { VA } 3 \\
00: 00\end{array}$ & $\begin{array}{l}\text { VA } 4 \\
09: 00\end{array}$ & $\begin{array}{l}\text { V4B } 1 \\
06: 00\end{array}$ & $\begin{array}{l}\text { V4B } 2 \\
12: 00\end{array}$ & $\begin{array}{l}\text { V4B } 3 \\
18: 00\end{array}$ & $\begin{array}{l}\text { V4B } 4 \\
00: 00\end{array}$ & $\begin{array}{l}\text { Total no. of } \\
\text { specimens }\end{array}$ & $\begin{array}{c}\mathrm{F} \\
(\%)\end{array}$ \\
\hline Thysanopoda aequalis & 0.00 & 0.00 & 21.88 & 0.00 & 0.00 & 0.00 & 0.00 & 0.00 & 21.88 & 5.09 \\
\hline Euphausia krohni & 0.00 & 0.00 & 21.88 & 0.00 & 14.86 & 0.00 & 0.00 & 7.27 & 44.01 & 10.24 \\
\hline E. brevis & 0.00 & 0.00 & 7.29 & 0.00 & 0.00 & 0.00 & 0.00 & 0.00 & 7.29 & 1.70 \\
\hline E. hemigibba & 0.00 & 0.00 & 43.76 & 0.00 & 7.43 & 0.00 & 0.00 & 0.00 & 51.19 & 11.91 \\
\hline Nematoscelis megalops & 0.00 & 0.00 & 29.17 & 4.87 & 0.00 & 0.00 & 0.00 & 0.00 & 34.04 & 7.92 \\
\hline N. atlantica & 0.00 & 0.00 & 14.59 & 0.00 & 0.00 & 0.00 & 0.00 & 0.00 & 14.59 & 3.40 \\
\hline Stylocheiron suhmi & 5.90 & 0.00 & 0.00 & 4.87 & 0.00 & 0.00 & 0.00 & 0.00 & 10.77 & 2.51 \\
\hline S. longicorne & 17.71 & 7.82 & 14.59 & 24.35 & 0.00 & 0.00 & 8.95 & 14.54 & 87.96 & 20.47 \\
\hline S. abbreviatum & 11.81 & 15.65 & 29.17 & 4.87 & 14.86 & 0.00 & 8.95 & 72.70 & 158.01 & 36.77 \\
\hline Total & 35.42 & 23.47 & 182.33 & 38.96 & 37.15 & 0.00 & 17.90 & 94.51 & 429.74 & 100.00 \\
\hline \multicolumn{11}{|l|}{ Eastern Mediterranean } \\
\hline Stn & Viera 1 & Viera 2 & Viera 3 & V10 1 & V1 & & & V10 4 & Total no. of & $\mathrm{F}$ \\
\hline Time sampling & $12: 00$ & $18: 00$ & $22: 00$ & $22: 00$ & 00 & & & $12: 00$ & specimens & $(\%)$ \\
\hline Thysanopoda aequalis & 0.00 & 0.00 & 0.00 & 0.00 & & & 00 & 0.00 & 16.67 & 5.14 \\
\hline Euphausia krohni & 0.00 & 0.00 & 0.00 & 0.00 & & & 52 & 0.00 & 26.19 & 8.07 \\
\hline E. brevis & 0.00 & 0.00 & 0.00 & 49.82 & & & 00 & 0.00 & 74.82 & 23.05 \\
\hline E. hemigibba & 0.00 & 0.00 & 23.95 & 29.89 & & & 00 & 0.00 & 62.17 & 19.16 \\
\hline Nematoscelis megalops & 0.00 & 0.00 & 0.00 & 0.00 & & & 00 & 0.00 & 8.33 & 2.57 \\
\hline N. atlantica & 0.00 & 0.00 & 0.00 & 0.00 & & & 00 & 0.00 & 0.00 & 0.00 \\
\hline Stylocheiron suhmi & 0.00 & 0.00 & 0.00 & 9.96 & & & 00 & 0.00 & 9.96 & 3.07 \\
\hline S. longicorne & 0.00 & 9.16 & 0.00 & 9.96 & & & 00 & 0.00 & 27.45 & 8.46 \\
\hline S. abbreviatum & 0.00 & 0.00 & 0.00 & 29.89 & & & & 0.00 & 98.94 & 30.49 \\
\hline Total & 0.00 & 9.16 & 23.95 & 129.52 & 133 & & & 0.00 & 324.53 & 100.00 \\
\hline
\end{tabular}

Table 6. Abundances (ind. $\mathrm{m}^{-3}$ ) of strong migrant copepod species in the samples taken at different times at the 2 westernmost and the 2 easternmost Mediterranean stations

\begin{tabular}{|c|c|c|c|c|c|c|c|c|}
\hline \multicolumn{9}{|l|}{ Western Mediterranean } \\
\hline Time sampling & $12: 00$ & $18: 00$ & 00:00 & 09:00 & 06:00 & $12: 00$ & $18: 00$ & 00:00 \\
\hline Paraeuchaeta acuta & 0 & 0 & 0 & 0 & 0 & 0 & 0 & 0 \\
\hline Pleuromamma abdominalis & 0 & 0 & 0 & 0 & 0.01 & 0 & 0 & 0.02 \\
\hline Pleuromamma gracilis & 0 & 0 & 0 & 0.01 & 0.05 & 0 & 0 & 0 \\
\hline \multicolumn{9}{|l|}{ Eastern Mediterranean } \\
\hline Stn & Viera 1 & Viera 2 & Viera 3 & & V10 1 & V10 2 & V10 3 & V10 4 \\
\hline Time sampling & $12: 00$ & $18: 00$ & $22: 00$ & & $22: 00$ & 00:00 & 08:30 & $12: 00$ \\
\hline Paraeuchaeta acuta & 0 & 0 & 0 & & 0 & 0 & 0 & 0 \\
\hline Pleuromamma abdominalis & 0 & 0 & 0 & & 0 & 0 & 0 & 0 \\
\hline Pleuromamma gracilis & 0 & 0 & 0 & & 0.01 & 0.01 & 0 & 0 \\
\hline
\end{tabular}

Concerning copepod composition, significant differences in total density and the presence of weak migrant species were not observed between night and day. Attention was also given to strong migrant species, such as Paraeuchaeta acuta, Pleuromamma gracilis and $P$. abdominalis, to detect behaviours that might be correlated to the ETS-data trends. Table 6 reports the density of these species in the samples taken at different times at the 2 western- and easternmost sampling stations, showing higher values in nighttime samples (sunset to sunrise, 21:00 to 07:00 h).

\section{Zooplankton biomass and related carbon requirement}

The biomass values of all samples taken at all 10 stations at different times of the day are reported in Table 7.

The zooplankton biomass $\left(\mathrm{mg} \mathrm{m}^{-3}\right)$ values obtained for the 2 western- and easternmost sampling stations are shown in Fig. 5a. Higher mean values were obtained for Stn V4B (15.53) and Stn V10 (9.02) compared with Stn VA (8.33) and Stn Viera (3.33). The carbon requirement of the community $\left(\mu \mathrm{g} \mathrm{C} \mathrm{m}^{-3} \mathrm{~d}^{-1}\right)$ at the 
intervals sampled was calculated by multiplying the biomass value $\left(\mathrm{g} \mathrm{m}^{-3}\right)$ and the measured carbon demand based on ETS activity ( $\mu \mathrm{g} \mathrm{C} \mathrm{g}^{-1} \mathrm{~d}^{-1}$ ) (Fig. 5b).

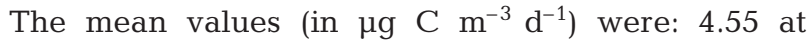
Stn V4B, 3.82 at Stn V10, 2.01 at Stn VA and 1.33 at Stn Viera. The highest community carbon requirements were observed in those samples that had a high carbon demand per $g$ biomass combined with a higher total biomass.

\section{DISCUSSION}

In the present study, information on the carbon consumption ( $\mu \mathrm{g} \mathrm{C} \mathrm{g}^{-1} \mathrm{~d}^{-1}$ ) by zooplankton in the 0 to $200 \mathrm{~m}$ layer at different stations in the Mediterranean Sea was obtained. All 10 stations were sampled during less than 1 mo (first sampling on 29 May, last on 23 June 2007), so we consider the samples as quasisynoptic and compare the results obtained from them.

To evaluate the role of zooplankton in the carbon flow in the pelagic ecosystem, ETS values were converted to carbon demand. The carbon requirements per unit of zooplankton biomass indicate diel and spatial geographical differences in the study area. There was a clear lower mean activity at the 5 stations in the western compared with the 5 stations in the eastern Mediterranean Sea. An increasing gradient from the Strait of Gibraltar towards the easternmost station near the Isle of Rhodes was evident. This increasing west-east gradient, validated by statistical analysis, was also observed separately for all morning, midday, afternoon and midnight samples. Considering that there were no significant differences in total zooplankton density and composition between the western and eastern sector, and that there was an almost equal ratio between gelatinous and crustacean taxa from west (mean ratio 1:7.2) to east (mean ratio 1:7), the trend in increasing carbon demand, confirmed by ANOVA, could be explained by a relationship between zooplankton ETS activity and seawater temperature. In fact, there is evidence (Packard et al. 1974, Finlay et al. 1983, Schalk 1988, Koppelmann \& Weikert 2003, Koppelmann et al. 2004) of a relationship between ETS activity and environmental temperature based on the measurement of enzymatic levels at different temperatures in the lab and recalculation of ETS activity using the Arrhenius equation (Owens \& King 1975). An increase by only a few degrees leads to higher enzymatic activities. It has been shown that the temperature profile from the ocean surface to deeper layers exhibits the same decreasing trend as zooplankton ETS activity (Schalk 1988). The same linear relationship had already been demonstrated by Packard et al. (1974), who reported that $90 \%$ of the differences in
Table 7. Biomass values (wet and dry weights, WW and DW) for the 35 collected samples

\begin{tabular}{|c|c|c|c|}
\hline Station & Sample & $\mathrm{WW}\left(\mathrm{mg} \mathrm{m}^{-3}\right)$ & $\mathrm{DW}\left(\mathrm{mg} \mathrm{m}^{-3}\right)$ \\
\hline VA & 1 & 8.98 & 0.72 \\
\hline VA & 2 & 8.79 & 0.91 \\
\hline VA & 3 & 8.78 & 0.87 \\
\hline VA & 4 & 6.78 & 0.66 \\
\hline V4B & 1 & 20.09 & 1.69 \\
\hline V4B & 2 & 16.88 & 1.23 \\
\hline V4B & 3 & 12.78 & 0.84 \\
\hline V4B & 4 & 12.37 & 1.13 \\
\hline V3B & 1 & 9.76 & 0.73 \\
\hline V3B & 2 & 7.41 & 0.60 \\
\hline V3B & 3 & 6.99 & 0.59 \\
\hline V1A & 1 & 8.39 & 1.09 \\
\hline V1A & 2 & 7.04 & 0.87 \\
\hline V1A & 3 & 6.05 & 0.66 \\
\hline V1A & 4 & 9.01 & 0.98 \\
\hline V2 & 1 & 3.75 & 0.53 \\
\hline V2 & 2 & 4.83 & 0.52 \\
\hline V2 & 3 & 5.05 & 0.57 \\
\hline V2 & 4 & 6.20 & 0.59 \\
\hline V6 & 1 & 4.52 & 0.39 \\
\hline V6 & 2 & 2.64 & 0.27 \\
\hline V6 & 3 & 5.01 & 0.50 \\
\hline V7 & 1 & 4.18 & 0.62 \\
\hline V7 & 2 & 3.66 & 0.41 \\
\hline V7 & 3 & 4.10 & 0.48 \\
\hline V8 & 1 & 1.78 & 0.25 \\
\hline V8 & 2 & 1.78 & 0.24 \\
\hline V8 & 3 & 2.29 & 0.28 \\
\hline VIERA & 1 & 3.92 & 0.44 \\
\hline VIERA & 2 & 1.76 & 0.22 \\
\hline VIERA & 3 & 4.32 & 0.53 \\
\hline V10 & 1 & 6.33 & 0.77 \\
\hline V10 & 2 & 12.78 & 1.13 \\
\hline V10 & 3 & 7.59 & 0.69 \\
\hline V10 & 4 & 9.40 & 1.45 \\
\hline
\end{tabular}

geographical ETS activity are due to differences in temperature. Analysing our ETS data, it is evident that the spatial distribution of ETS activity, and thus of carbon and $\mathrm{O}_{2}$ demand, is influenced by temperature values. The mean temperature at the 5 western stations was $15.1^{\circ} \mathrm{C}$ with a minimum value of $13.8^{\circ} \mathrm{C}$, while for the eastern stations the mean temperature was $16.8^{\circ} \mathrm{C}$ with a maximum value of $18.4^{\circ} \mathrm{C}$. Zooplankton samples from stations with higher temperatures, as in the Levantine Basin, showed higher ETS values because metabolic activities, like the remineralization of organic material, are directly correlated with temperature.

Furthermore, among the different sampling times, ETS activity peaks were recorded in the samples taken at midnight or in the morning before sunrise, followed (in decreasing order) by afternoon and midday collections. For this reason, we hypothesize that this could be 

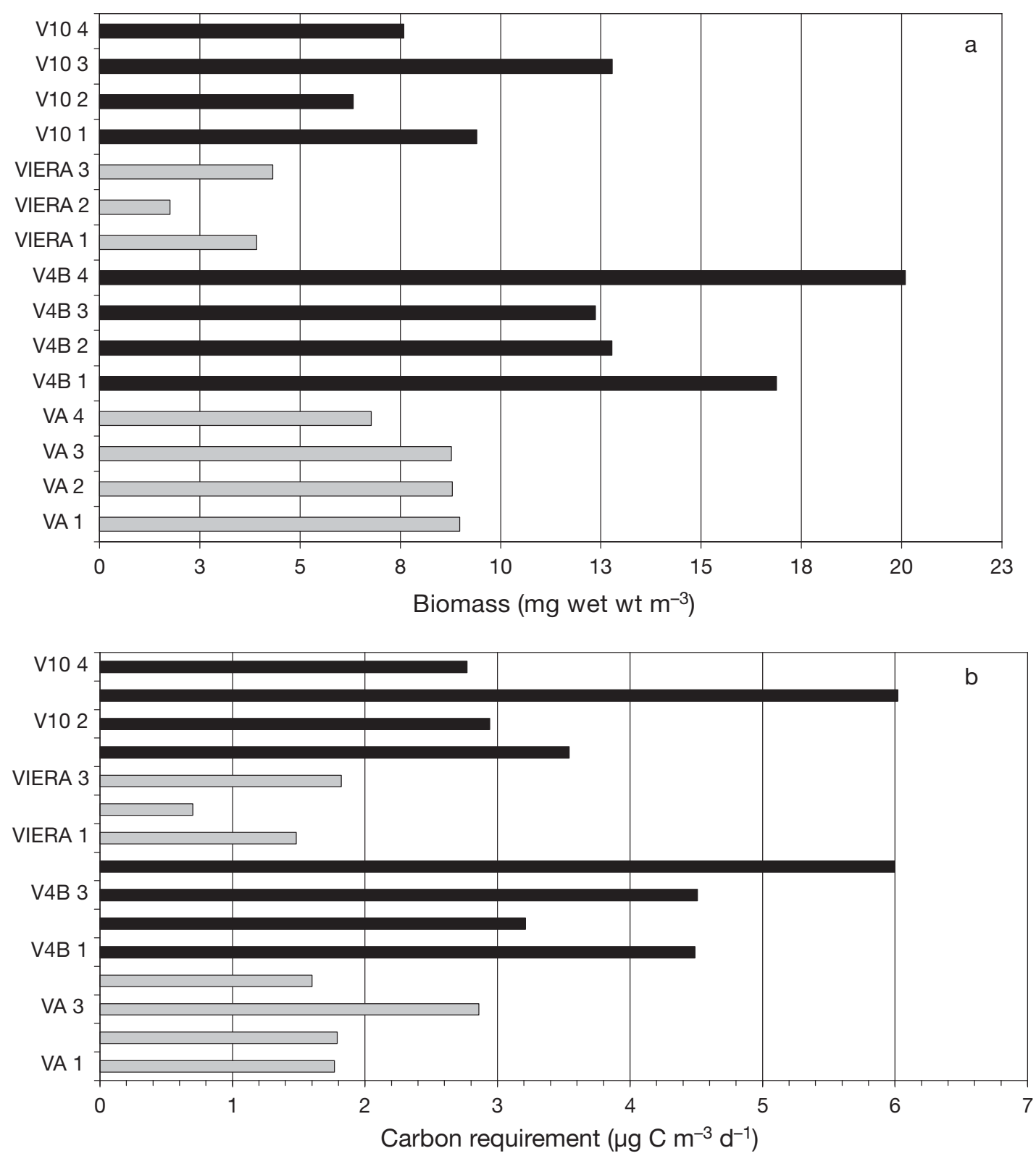

Fig. 5. Zooplankton (a) wet weight biomass and (b) metabolic carbon requirement from samples taken at 0 to $200 \mathrm{~m}$ depth at Stns VA and V4B (western Mediterranean) and Viera and V10 (eastern Mediterranean) at 1: midday (12:00 h), 2: afternoon (18:00 h except Stn V10: 22:00 h), 3: midnight 00:00 h except Stn Viera: 22:00 h), 4: morning (06:00 h except Stns VA: 09:00 h and V10: 08:30 h)

due to a change in composition of the layer. However, the ETS activity was standardized per $\mathrm{g}$ biomass, so differences only in density do not explain this phenomenon, although oxygen demand is a function of body mass (Ikeda et al. 2001). This was, therefore, probably caused by actively migrating organisms that mediate the vertical transport of material in the sea (Longhurst 1976, Longhurst et al. 1990). The euphausiid species composition analysis on the samples taken at different times revealed that adult and furcilia stages of euphausiids actively migrated from deeper layers into the top 0 to $200 \mathrm{~m}$ layer during nighttime, residing in the deeper layers during the day. It is well known that euphasiids show diel vertical migration, feeding in upper layers at night and returning to deeper and colder layers during the day to avoid predators (Brinton 1967, Mauchline \& Fisher 1969, Vinogradov 1970, Casanova 1974, Lampert 1993, Brancato et al. 2001). In fact, in our samples, during the diel cycle, some species such as Thysanopoda aequalis, Euphausia spp. and Nematoscelis megalops showed a strong migratory behaviour in both basins. The small number or com- 
plete absence of specimens in morning and midday samples showed that the majority of these taxa occurred below $200 \mathrm{~m}$ depth at these times. In the nighttime samples, the number of individuals increased as the euphausiids concentrated in the upper layer.

The total abundance of copepod species did not differ between daytime and nighttime, which may be due to the sampled 0 to $200 \mathrm{~m}$ layer being too wide to study the behaviour of weak migrants such as Corycaeus furcifer, Oncaea conifera, Heterorhabdus papilliger or Scolecithricella dentata (Scotto di Carlo et al. 1984). In contrast, the strong migrant copepods, such as Pleuromamma abdominalis, $P$. gracilis and Paraeuchaeta acuta, showed a typical migratory behaviour. They were absent in the midday and afternoon samples, but present in the night collections.

Hence, mainly the euphausiids but also the copepods are responsible for the increasing ETS activity per biomass unit of zooplankton ( $\mathrm{g} \mathrm{m}^{-3}$ wet $\mathrm{wt}$ ) during the day and at night (Torres et al. 1979, Schalk 1988). That migrating euphausiid species have a higher ETS activity than the deeper-living and non-migrating species in the pelagic environment has been reported previously (Childress 1969, 1971, 1975, Jannasch \& Wirsen 1973, Packard et al. 1975, Jannasch et al. 1976, Torres et al. 1979).

The ratio of living to dead specimens has no relevance in our study because only a small number of dead copepods was found in 4 out of 30 samples (the highest value was $1.48 \%$ of total zooplankton abundance in the midday sample at Stn Viera).

The eastern Mediterranean Sea is a very oligotrophic region with low species richness and abundance compared to the western part and most other marine ecosystems in the world (Redfield et al. 1963, Scotto di Carlo \& Ianora 1983, Dugdale \& Wilkerson 1988, Weikert \& Trinkaus 1990, Kerhervè et al. 1999). Based on our results, it is possible to say that the high metabolic carbon demand of the zooplankton in the eastern part of the Mediterranean Sea contributes to the carbon losses from the POC sinking flux in the water column (Koppelmann \& Weikert 2003), amplifying the features of an impoverished region.

Furthermore, the higher carbon demand in the Levantine sector is not accompanied by higher primary production compared with the western sector. According to V. Saggiomo (pers. comm.), there is a decreasing trophic gradient from west to east. The total biomass $( \pm \mathrm{SD})$ was, in fact, between 0.03 and $1.93 \mathrm{mg} \mathrm{chl} \mathrm{a} \mathrm{m} \mathrm{m}^{-3}$ $( \pm 0.33)$ in the western sector and between 0.03 and $0.48 \mathrm{mg} \mathrm{chl} \mathrm{a} \mathrm{m} \mathrm{m}^{-3}( \pm 0.12)$ in the eastern sector, with primary production values between 0.04 and $3.59 \mathrm{mg}$ $\mathrm{C} \mathrm{m}^{-3} \mathrm{~h}^{-1}( \pm 0.82)$ and between 0.09 and $0.57 \mathrm{mg} \mathrm{C} \mathrm{m}^{-3}$ $\mathrm{h}^{-1}( \pm 0.11)$, respectively.
The zooplankton compartment, recycling POM originating in the epipelagic layer, contributes to the decrease of material that can reach the bottom and the biotic communities that live in deeper layers (Thiel 1983, Tselepides \& Eleftheriou 1992). The remaining carbon losses in the water column may be due to requirements by other size classes and/or by transfer into the dissolved organic carbon pool.

Acknowledgements. Thanks to the National Interuniversitary Consortium for Marine Sciences (CoNISMa) as the scientific responsible coordinator of the VECTOR Italian project, developed with the Special Integrative Fund Research (FISR)-Call 2001. Our local research unit (CoNISMa Messina) was involved in Line 8 of the project, CARPEL (The CARbon cycle in the PELagic area of the Mediterranean), Tasks 1 'South Adriatic Sea', 2 'South Tyrrhenian Sea' and 5 'Oceanographic cruise, Basin Scale', Subtask 'Epipelagic and Meso-bathypelagic Trophic Chain'. Thank you to the crew of the Oceanographic Vessel 'Universitatis' for the efficient collaboration in the collection of samples. A special thank you goes to R. Koppelmann for the kind and prompt assistance with the analytical methodology.

\section{LITERATURE CITED}

Bamstedt U (1979) Seasonal variation in respiratory rate and ETS activity of deep water zooplankton from the Swedish west coast. In: Naylor E, Hartnoll RG (eds) Cyclic phenomena in marine plants and animals, Proc 13th Eur Mar Biol Symp. Pergamon Press, Oxford, p 267-274

Bamstedt U (1980) ETS activity as an estimator of respiratory rate of zooplankton populations. The significance of variations in an environmental factor. J Exp Mar Biol Ecol 42: $267-283$

Berger WH, Smetacek VS, Wefer G (1988) Ocean productivity and paleoproductivity-an overview. In: Berger $\mathrm{WH}$, Smetacek VS, Wefer G (eds) Productivity of the ocean: present and past. Life sciences research report, Vol 44. Wiley, Chichester, p 1-34

Bidigare RR, King FD, Biggs DC (1982) Glutamate dehydrogenase and respiratory electron transport system activities in the Gulf of Mexico zooplankton. J Plankton Res 4:895-912

> Bradford-Grieve JM, Nodder SD, Jillett JB, Currie K, Lassey KR (2001) Potential contribution that the copepod Neocalanus tonsus makes to downward carbon flux in the Southern Ocean. J Plankton Res 23:963-975

Brancato G, Minutoli R, Granata A, Sidoti O, Guglielmo L (2001) Diversity and vertical migration of euphausiids across the Straits of Messina area. In: Faranda FM, Guglielmo L, Spezie G (eds) Mediterranean ecosystems: structure and processes., Springer Verlag Italia, Milan

Brinton E (1967) Vertical migration and avoidance capability of euphausiids in the California Current. Limnol Oceanogr 12:451-483

Casanova B (1974) Les Euphausiaces de Mediterranee: systematique et developpement larvaire: biogeography et biologie. PhD thesis, University of the Provence, Marseille

Childress JJ (1969) The respiratory physiology of the oxygen minimum layer mysid Gnatthophausia ingens. $\mathrm{PhD}$ dissertation, Stanford University, Stanford, CA

Childress JJ (1971) Respiratory rate and depth of occurrence of midwater animals. Limnol Oceanogr 16:104-106 
Childress JJ (1975) The respiratory rates of midwater crustaceans as a function of depth of occurrence and relation to the oxygen minimum layer off Southern California. Comp Biochem Physiol A 50:787-799

Christiansen B, Beckmann W, Weikert W (2001) The structure and carbon demand of the bathyal benthic boundary layer community: a comparison of two oceanic locations in the NE-Atlantic. Deep-Sea Res II 48:2409-2424

Conover RJ (1959) Regional and seasonal variation in respiratory rate of marine copepods. Limnol Oceanogr 4:259-268

Conover RJ, Corner EDS (1968) Respiration and nitrogen excretion by some marine zooplankton in relation to their life cycles. J Mar Biol Assoc UK 48:49-75

Devol AH, Packard TT (1978) Seasonal changes in respiratory enzyme activity and productivity in Lake Washington microplankton. Limnol Oceanogr 23:104-111

Dugdale RC, Wilkerson FP (1988) Nutrient resources and primary production in the eastern Mediterranean. Oceanol Acta 9:179-184

Finlay BJ, Span A, Ochsenbein-Gattlen C (1983) Influence of physiological state in indices of respiration rate in protozoa. Comp Biochem Physiol A 74:211-219

Gaudy R (1973) Les variations saisonieres de la respiration chez quatre especes de copepods pelagiques de Golfe de Marseille. Neth J Sea Res 7:267-279

Halsband-Lenk C, Koppelmann R, Weikert H (2003) Carbon requirements of deep-sea zooplankton estimated from ETS measurements in relation to size fraction and taxonomic composition. In: Yalmaz A (ed) Oceanography of Eastern Mediterranean and Black Sea. Tubitak, Ankara, p 805-813

Hernández-León SM, Gómez M (1996) Factors affecting the Respiration/ETS ratio in marine zooplankton. J Plankton Res 18:239-255

Hirche HJ (1984) Temperature and metabolism of plankton. I. Respiration of Antarctic zooplankton at different temperatures with a comparison of Antarctic and Nordic krill. Comp Biochem Physiol 77A:361-368

Ikeda T, Hing Fay E (1981) The metabolic activity of zooplankton from the Antarctic Ocean. Aust J Mar Freshw Res 32: 921-930

Ikeda T, Kanno Y, Ozaki K, Shinada A (2001) Metabolic rates of marine copepods as a function of body mass and temperature. Mar Biol 139:587-596

Jannasch HW, Wirsen CO (1973) Deep-sea microorganisms: in situ response to nutrient enrichment. Science 180: 641-643

Jannasch HW, Wirsen CO, Taylor CD (1976) Undecompressed microbial population from the deep-sea. Appl Environ Microbiol 32:360-367

Kenner RA, Ahmed SJ (1975a) Measurement of electron transport activities in marine phytoplankton. Mar Biol 33: 119-127

Kenner RA, Ahmed SJ (1975b) Correlation between oxygen utilization and electron transport activity in marine phytoplankton. Mar Biol 33:119-127

Kerhervè $\mathrm{P}$, Heussner S, Charriere B, Stavrakakis S, Ferranf JL, Monaco A, Delsaut N (1999) Biogeochemistry and dynamics of settling particle fluxes at the Antikythira Strait (Eastern Mediterannean). Prog Oceanogr 44: 651-675

King FD, Packard TT (1975) Respiration and the activity of respiratory electron transport system in marine zooplankton. Limnol Oceanogr 20:849-854

King FD, Devol AH, Packard TT (1978) On plankton biomass and metabolic activity from the eastern tropical North Pacific. Deep-Sea Res 25:689-704
Koppelmann R, Weikert H (2003) Deep-sea zooplankton ecology of the eastern Mediterranean. State of the art and perspectives. CIESM Workshop Monographs 23:47-53

> Koppelmann R, Schafer P, Schiebel R (2000) Organic carbon losses measured by heterotrophic activity of mesozooplankton and $\mathrm{CaCO}_{3}$ flux in the bathypelagic zone of the Arabian Sea. Deep-Sea Res II 47:169-187

Koppelmann R, Weikert H, Halsband-Lenk C (2004) Mesozooplankton community respiration and its relation to particle flux in the oligotrophic eastern Mediterranean. Global Biogeochem Cycles 18:GB1039, doi:10.1029/ 2003GB002121

> Lampitt RS (1992) The contribution of deep-sea macroplankton to organic remineralization: results from sediment trap and zooplankton studies over the Madeira abyssal Plain. Deep-Sea Res 39:221-233

Longhurst AR (1976) Vertical migration. In: D.H. Cushing DH, Walsh JJ (eds) The ecology of the seas. Blackwell Scientific, Oxford, p 116-137

Longhurst AR (1991) Role of the marine biosphere in the global carbon cycle. Limnol Oceanogr 36:1507-1526

> Longhurst AR, Bedo AW, Harrison WG, Head EJH, Sameoto DD (1990) Vertical flux of respiratory carbon by oceanic diel migrant biota. Deep-Sea Res 37:685-694

- Marschoff ER, Lovrich GA, Calcagno JA (1989) Vertical distribution of two substages of stage Calyptopis I of Euphausia superba Dana, in South Orkneys Area. Polar Biol 9: $325-328$

- Marshall SM (1973) Respiration and feeding in copepods. Adv Mar Biol 11:57-120

Marshall SM, Orr AP (1956) On the biology of Calanus fimmarchicus X. Seasonal changes in oxygen consumption. J Mar Biol Assoc UK 37:459-472

Mauchline J, Fisher LR (eds) (1969) The biology of euphausiids. Academic Press, New York

$>$ Owens TG, King FD (1975) The measurement of respiratory electron transport system activity in marine zooplankton. Mar Biol 30:27-36

Packard TT (1971) The measurement of electron transport system activity in marine phytoplankton. J Mar Res 29: $235-244$

Packard TT, Richards FA (1971) Vertical distribution of the activity of the respiratory electron transport system in marine plankton. Limnol Oceanogr 16:60-70

Packard TT, Harmon D, Boucher J (1974) Respiratory electron transport activity in plankton from upwelled waters. Tethys 6:213-222

Packard TT, Devol AH, King FD (1975) The effect of temperature on the respiratory electron transport system in marine plankton. Deep-Sea Res 22:237-249

Raymont JEG (1983) Plankton and productivity in the oceans, Vol 2, Zooplankton. Pergamon Press, Oxford

Redfield AC, Ketchum BH, Richards FA (1963) The influence of organisms on the composition of sea-water. In: Hill M (ed) The Sea, Vol 2. Wiley Interscience, New York, p 26-77

Sasaki H, Hattori H, Nishizawa S (1988) Downward flux of particulate organic matter and vertical distribution of calanoid copepods in the Oyashio Water in summer. DeepSea Res I 35:505-515

> Schalk PH (1988) Respiratory electron transport system (ETS) activities in zooplankton and micronekton of the IndoPacific region. Mar Ecol Prog Ser 44:25-35

Scotto di Carlo B, Ianora A (1983) Standing stocks and species composition of Mediterranean zooplantkon. In: Carrada GC, Hopkins T, Jeftié LJ, Morcos S (eds) Quantitative analysis and simulation of Mediterranean coastal ecosystems: the 
Gulf of Naples, a case study. Report of a workshop on ecosystem modelling (Naples, Italy, March 28-April 10, 1981) UNESCO Reports in Marine Science 20:59-69

Scotto di Carlo B, Ianora A, Fresi E, Hure J (1984) Vertical zonation patterns for Mediterranean copepods from the surface to $3000 \mathrm{~m}$ at a fixed station in the Thyrrenian sea. J Plankton Res 6:1031-1056

Smith KL Jr (1982) Zooplankton of a bathyal boundary layer: in situ rates of oxygen consumption and ammonium excretion. Limnol Oceanogr 27:461-471

Smith KL Jr (1987) Food energy supply and demand: a discrepancy between particulate organic carbon flux and sediment community oxygen consumption in the deep ocean. Limnol Oceanogr 32:201-220

Steedman HF (1976) General and applied data on formaldehyde fixation and preservation of marine zooplankton. In: Steedman HF (ed) Zooplankton fixation and preservation. UNESCO, Paris, p 103-154

Steinberg DK, Silver MW, Pilskaln CH (1997) Role of mesopelagic zooplankton in the community metabolism of giant larvacean house detritus in Monterey Bay, California, USA. Mar Ecol Prog Ser 147:167-179

Stuart V, Pillar SC (1990) Diel grazing patterns of all ontogenetic stages of Euphausia lucens and in situ predation rates on copepods in the southern Benguela upwelling region. Mar Ecol Prog Ser 64:227-241

Editorial responsibility: Hans Heinrich Janssen, Oldendorf/Luhe, Germany
Thiel H (1983) Meiobenthos and nanobenthos of the deepsea. In: Rowe GT (ed) The sea, Vol 8. Wiley, New York, p 167-230

Torres JJ, Belman BW, Childress JJ (1979) Oxygen consumption of midwater fishes as a function of depth of occurrence. Deep-Sea Res 26:185-197

Tranter DJ (1962) Zooplankton abundance in Australasian waters. Aust J Mar Freshw Res 13:106-142

Tselepides A, Eleftheriou A (1992) South Aegean (Eastern Mediterranean) continental slope benthos: macroinfaunal-environmental relationships. In: Rowe GT, Pariente V (eds) Deep-sea food chains and the global carbon cycle. Dordecht, Kluwer Academic, 139-156

Vinogradov ME (1970) Vertical distribution of the oceanic zooplankton. Israel Program for Scientific Translations, Jerusalem. (Translation of: Vertikal'noe raspredelenie okeanicheskogo zooplanktona. Akademiya nauk SSSR Institut Okeanologii, Moscow, 1968)

Weikert H, Trinkaus S (1990) Vertical mesozooplankton abundance and distribution in the deep Eastern Mediterranean Sea SE of Crete. J Plankton Res 12:601-628

> Yamaguchi A, Watanabe Y, Ishida H, Harimoto T and others (2002) Community and trophic structure of pelagic copepods down to greater depths in the western subarctic Pacific (WEST-COSMIC). Deep-Sea Res I 49: 1007-1025

Submitted: July 1, 2008; Accepted: November 26, 2008 Proofs received from author(s): April 7, 2009 